\title{
Relaxor-Ferroelectric Films for Dielectric Tunable Applications: Effect of Film Thickness and Applied Electric Field
}

\author{
Minh D. Nguyen ${ }^{1,2, *}$, Doan T. Tran ${ }^{2}$, Ha T. Dang ${ }^{2,3}$, Chi T. Q. Nguyen ${ }^{2,3}$, Guus Rijnders ${ }^{1}$ and Hung N. Vu ${ }^{2, *}$ \\ 1 MESA+ Institute for Nanotechnology, University of Twente, P.O. Box 217, \\ 7500AE Enschede, The Netherlands; a.j.h.m.rijnders@utwente.nl \\ 2 International Training Institute for Materials Science (ITIMS), Hanoi University of Science and Technology, \\ 1 Dai Co Viet Road, Hanoi 100000, Vietnam; doantranthi97@gmail.com (D.T.T.); \\ danghaktck@gmail.com (H.T.D.); chintq@vnuf.edu.vn (C.T.Q.N.) \\ 3 Mechanics and Civil Engineering, Vietnam National University of Forestry, Chuong My District, \\ Hanoi 100000, Vietnam \\ * Correspondence: d.m.nguyen@utwente.nl (M.D.N.); hung.vungoc@hust.edu.vn (H.N.V.)
}

Citation: Nguyen, M.D.; Tran, D.T.; Dang, H.T.; Nguyen, C.T.Q.; Rijnders, G.; Vu, H.N. Relaxor-Ferroelectric Films for Dielectric Tunable Applications: Effect of Film Thickness and Applied Electric Field. Materials 2021, 14, 6448. https://doi.org/ $10.3390 /$ ma14216448

Academic Editor: Miguel Algueró

Received: 29 September 2021

Accepted: 25 October 2021

Published: 27 October 2021

Publisher's Note: MDPI stays neutral with regard to jurisdictional claims in published maps and institutional affiliations.

Copyright: (C) 2021 by the authors. Licensee MDPI, Basel, Switzerland. This article is an open access article distributed under the terms and conditions of the Creative Commons Attribution (CC BY) license (https:/ / creativecommons.org/licenses/by/ $4.0 /)$.

\begin{abstract}
The dielectric properties, tunability and figure-of-merit $(F O M)$ of relaxor $\mathrm{Pb}_{0.9} \mathrm{La}_{0.1}\left(\mathrm{Zr}_{0.52} \mathrm{Ti}_{0.48}\right) \mathrm{O}_{3}$ (PLZT) films have been investigated. Dielectric measurements indicated that the dielectric constant (at zero-bias field), tunability and FOM are enhanced as the film thickness increases, which are mainly attributed to the presence of an interfacial layer near the film-electrode interface. Experimental results illustrated that a slight reduction is observed in both dielectric constant and tunability $(-2 \%)$ in a wide-frequency range $(10 \mathrm{kHz}-1 \mathrm{MHz})$; meanwhile, the FOM value decreases significantly $(-17 \%)$ with increasing frequency, arising from the higher dielectric loss value. The 1000-nm PLZT film shows the largest tunability of $94.6 \%$ at a maximum electric-field of $1450 \mathrm{kV} / \mathrm{cm}$, while the highest FOM factor is 37.6 at $1000 \mathrm{kV} / \mathrm{cm}$, due to the combination of medium tunability $(88.7 \%)$ and low dielectric loss (0.0236). All these excellent results indicated that the relaxor PLZT films are promising candidates for specific applications in microwave devices.
\end{abstract}

Keywords: dielectric properties; tunability; figure-of-merit; relaxor ferroelectrics

\section{Introduction}

Tunable microwave devices are currently of high interest for applications as tunable dielectric filters, tunable delay lines and microwave phase shifts for steerable antennas [1-5]. In general, the tunable device can be a capacitor based on ferroelectric, ferromagnetic or a combination of ferroelectric/ferromagnetic materials. In these structures, an applied electric field can be used to alter the surface wave propagation by varying the dielectric constant of the ferroelectric layer, or by varying the permeability of the ferromagnetic layer by changing the applied magnetic field [3,6-10].

In ferroelectric-based tunable microwave devices, the high achievable tunability and low dielectric loss, corresponding to the large figure-of-merit (FOM) of the ferroelectric layer, are crucial parameters for their performance in practical applications. The tunability of a ferroelectric layer is determined by the following formula:

$$
T=\frac{\varepsilon_{r, 0 V}-\varepsilon_{E_{a p}}}{\varepsilon_{r, 0 V}} \times 100 \%
$$

where $\varepsilon_{r, 0 V}$ is the dielectric constant at zero-bias field and $\varepsilon_{E_{a p}}$ is the dielectric constant a certain bias applied field $\left(E_{a p}\right)$.

The FOM, which is normally used to reflect the trade-off of dielectric materials for tunable devices $[11,12]$, can be expressed as:

$$
F O M=\frac{\text { Tunability }}{\tan \delta}
$$


In Equation (2), the $F O M$ factor is calculated considering the tunability and dielectric loss at a zero-bias field.

The tunability and FOM of ferroelectric films has been widely studied in materials including lead- and lead-free perovskites, in which the dependence of these properties on film properties, such as crystalline quality and thickness, were discussed. In general, tunability increases with film crystallinity and thickness [13,14]. Recently, multilayer films have also been investigated for improving tunability and FOM [11,15-17]. Yu indicated that the tunability and FOM values of multilayer $x \mathrm{PbZr}_{0.52} \mathrm{Ti}_{0.48} \mathrm{O}_{3} /(1-x) \mathrm{Bi}_{1.5} \mathrm{Zn}_{1.0} \mathrm{Nb}_{1.5} \mathrm{O}_{7}$ (PZT/BZN) films can be changed by varying the PZT/BZN thickness ratio, and also by changing the number of layer in the structure [11]. Their results showed that the multilayer $[\mathrm{PZT} / \mathrm{BZN}]_{N=4}$ structure with PZT/BZN thickness ratio of 3:1 had a large dielectric constant and low dielectric loss at zero bias field, due to the contribution of the interfacial layer near the PZT /BZN interface, resulting in the enhancement of tunability $(\sim 53.3 \%)$ and $F O M(\sim 65.6)$. The tunability and FOM values of lead-based, lead-free and multilayer films are summarized in Table 1.

The applied electric field $\left(E_{a p}\right)$ dependent tunability, calculated from Equation (1), indicates that the tunability increases with increasing maximum applied electric field $\left(E_{a p, \max }\right)$, due to the decrease in $\varepsilon_{E_{a p, \max }}$ (as will be described in the next section), resulting in the increase of $\left(\varepsilon_{r, 0 V}-\varepsilon_{E_{a p, m a x}}\right)$. In previous work, we have reported that the electric breakdown strength $\left(E_{B D}\right)$ of relaxor-ferroelectric $\mathrm{Pb}_{0.9} \mathrm{La}_{0.1}\left(\mathrm{Zr}_{0.52} \mathrm{Ti}_{0.48}\right) \mathrm{O}_{3}$ (PLZT) films was much higher than that of normal-ferroelectric $\mathrm{Pb}\left(\mathrm{Zr}_{0.52} \mathrm{Ti}_{0.48}\right) \mathrm{O}_{3}$ (PZT) films [18]. More importantly, the $E_{B D}$ was also enhanced as the film thickness increased [19], which is contradictory to the inverse square root dependence of $E_{B D}$ on sample thickness $\left(t, E_{B D} \propto\right.$ $t^{-1 / 2}$ ) [20-23]. However, this inverse relationship is considered valid when the thickness of samples is greater than the critical thickness $\left(t_{\text {critical }} \approx 20 \mu \mathrm{m}\right)[20,23,24]$. This thicknessdependent breakdown strength regime is attributed to defects in the dielectric materials that can be introduced during fabrication process (extrinsic breakdown) [23]. Meanwhile, the thickness-independent breakdown strength of the dielectric materials was observed in thin sample ranges (lower than that of 200-500 nm, depending on the type of materials) [23]. In the PLZT films with a thickness range from $250 \mathrm{~nm}$ to $1000 \mathrm{~nm}$, increase in the film thickness was found to enhance the breakdown strength, which was attributed to the reduction of space-charge injection as result in the decrease in leakage current with increasing film thickness $[25,26]$.

In this study, we have investigated relaxor PLZT films with various film thicknesses in order to explore the correlation between applied electric field and dielectric, tunability and FOM properties. Moreover, the effect of applied frequency on the tunability and FOM of PLZT films has also been discussed in detail, as it determines the range of selectable frequencies for different microwave applications. The results in this study indicate that the relaxor-ferroelectric PLZT films with high breakdown strength demonstrate high tunability $(\sim 88.7 \%)$ and a large FOM $(\sim 37.6)$ at the high frequency of $100 \mathrm{kHz}$, making them a promising candidate for application in microwave tunable devices.

Table 1. Tunability and FOM of lead-based and lead-free films.

\begin{tabular}{ccccccc}
\hline Film & $\begin{array}{c}\text { Thickness } \\
(\mathbf{n m})\end{array}$ & $\begin{array}{c}E_{\text {ap, max }} \\
(\mathbf{k V / c m})\end{array}$ & $\begin{array}{c}\text { Frequency } \\
(\mathbf{k H z})\end{array}$ & $\begin{array}{c}\text { Tunability } \\
\mathbf{( \% )}\end{array}$ & FOM & Refs. \\
\hline $\mathrm{PbZr}_{0.52} \mathrm{Ti}_{0.48} \mathrm{O}_{3}$ & 1000 & 300 & 10 & 68.4 & 32.2 & {$[27]$} \\
\hline $\mathrm{Pb}_{0.92} \mathrm{La}_{0.08} \mathrm{Zr}_{0.52} \mathrm{Ti}_{0.48} \mathrm{O}_{3}$ & 690 & 300 & 10 & 68.9 & 19.1 & {$[28]$} \\
\hline $\mathrm{Pb}_{0.92} \mathrm{La}_{0.08} \mathrm{Zr}_{0.52} \mathrm{Ti}_{0.48} \mathrm{O}_{3}$ & 3000 & 1000 & 10 & 88.6 & 16.4 & {$[29]$} \\
\hline $\mathrm{Pb}_{0.92} \mathrm{La}_{0.08} \mathrm{Zr}_{0.52} \mathrm{Ti}_{0.48} \mathrm{O}_{3}$ & 3000 & 400 & 10 & 63.0 & 10.5 & {$[30]$} \\
\hline $\mathrm{Pb}_{0.4} \mathrm{Sr}_{0.6} \mathrm{TiO}_{3}$ & 500 & 300 & 1000 & 73.7 & 10.4 & {$[31]$} \\
\hline $\mathrm{Pb}\left(\mathrm{Zr}_{0.52} \mathrm{Ti}_{0.48} \mathrm{O}_{3} / \mathrm{Bi}_{1.5} \mathrm{Zn}_{1.0} \mathrm{Nb}_{1.5} \mathrm{O}_{7}\right.$ & 800 & 500 & 100 & 53.3 & 65.6 & {$[11]$} \\
\hline $\mathrm{BaSn}_{0.15} \mathrm{Ti}_{0.85} \mathrm{O}_{3}$ & 420 & 80 & 100 & 70.0 & 17.0 & {$[32]$} \\
\hline
\end{tabular}


Table 1. Cont.

\begin{tabular}{|c|c|c|c|c|c|c|}
\hline Film & $\begin{array}{c}\text { Thickness } \\
\text { (nm) }\end{array}$ & $\begin{array}{c}E_{a p, \max } \\
(\mathrm{kV} / \mathrm{cm})\end{array}$ & $\begin{array}{l}\text { Frequency } \\
\quad(\mathbf{k H z})\end{array}$ & $\begin{array}{c}\text { Tunability } \\
(\%)\end{array}$ & FOM & Refs. \\
\hline $\mathrm{Ba}_{0.6} \mathrm{Sr}_{0.4} \mathrm{TiO}_{3}$ & - & 300 & 1000 & 72.2 & 24.6 & [33] \\
\hline $\begin{array}{c}0.06 \mathrm{Nb}\left(\mathrm{Zn}_{1 / 2} \mathrm{Ti}_{1 / 2}\right) \mathrm{O}_{3}- \\
0.94 \mathrm{Ba}_{0.7} \mathrm{Sr}_{0.3} \mathrm{TiO}_{3}\end{array}$ & - & 300 & 1000 & 37.1 & 43.2 & [33] \\
\hline $\mathrm{Ba}_{0.45} \mathrm{Sr}_{0.55} \mathrm{TiO}_{3}$ & 250 & 640 & - & 78.0 & 16.3 & {$[34]$} \\
\hline $\begin{array}{c}0.04 \mathrm{Ba}\left(\mathrm{Mg}_{1 / 3} \mathrm{Nb}_{2 / 3}\right) \mathrm{O}_{3-}- \\
0.96 \mathrm{Ba}_{0.45} \mathrm{Sr}_{0.55} \mathrm{TiO}_{3}\end{array}$ & 250 & 640 & - & 72.0 & 24.0 & {$[34]$} \\
\hline $\mathrm{Pb}_{0.9} \mathrm{La}_{0.1} \mathrm{Zr}_{0.52} \mathrm{Ti}_{0.48} \mathrm{O}_{3}$ & 1000 & 800 & 1000 & 85.2 & 33.3 & \multirow{3}{*}{ This study } \\
\hline $\mathrm{Pb}_{0.9} \mathrm{La}_{0.1} \mathrm{Zr}_{0.52} \mathrm{Ti}_{0.48} \mathrm{O}_{3}$ & 1000 & 1000 & 100 & 88.7 & 37.6 & \\
\hline $\mathrm{Pb}_{0.9} \mathrm{La}_{0.1} \mathrm{Zr}_{0.52} \mathrm{Ti}_{0.48} \mathrm{O}_{3}$ & 1000 & 1450 & 100 & 94.6 & 34.4 & \\
\hline
\end{tabular}

\section{Experiment}

Relaxor-ferroelectric $\mathrm{Pb}_{0.9} \mathrm{La}_{0.1}\left(\mathrm{Zr}_{0.52} \mathrm{Ti}_{0.48}\right) \mathrm{O}_{3}$ (PLZT) films with different thicknesses of 250, 500 and $1000 \mathrm{~nm}$ were deposited on $100 \mathrm{~nm} \mathrm{SrRuO} 3$ (SRO) electrode-covered $\mathrm{SrTiO}_{3} / \mathrm{Si}$ 1-inch wafers, using pulsed laser deposition (PLD) method with a KrF excimer laser source (Lambda Physik, $248 \mathrm{~nm}$ wavelength). The deposition conditions of PLZT and SRO layers can be found in Ref. [19]. After deposition, the film capacitors with dimensions of $100 \mu \mathrm{m} \times 100 \mu \mathrm{m}$ were patterned and structured by argon-ion beam etching for the SRO top-electrodes and by wet-chemical etching ( $\mathrm{HF} / \mathrm{HCl}$ solution) for the PLZT films.

The crystalline orientation and microstructure of the films were analyzed via $\mathrm{X}$ ray diffraction $\theta-2 \theta$ scans (XRD), using a PANalytical X-ray diffractometer with $\mathrm{Cu}-\mathrm{K} \alpha$ radiation with a wavelength of $1.5405 \AA$, and also via cross-sectional scanning electron microscopy (SEM, Zeiss MERLIN). The polarization hysteresis $(P-E)$ loops and switching current $\left(I_{S W}-E\right)$ curves were measured with the dynamic mode (DHM) of the TF-2000 Analyzer (aixACCT GmbH, Aachen, Germany). The capacitance-electric field (C-E) curves were done with the capacitance module of the TF-2000 Analyzer. A slowly sweeping dc-bias field with a small ac-field $(10 \mathrm{kV} / \mathrm{cm})$ and in the frequency range of $10 \mathrm{kHz}$ to $1 \mathrm{MHz}$ was applied during the capacitance measurement. The dielectric constant and dielectric loss were evaluated from the corresponding $C-E$ curves.

\section{Results and Discussion}

Figure 1a shows the XRD $\theta-2 \theta$ scans of PLZT films, in which only the $(00 l) /(100)$-type diffraction peaks are observed. The out-of-plane $c$-lattice parameters, calculated from the position of the (002) peaks, are approximately 4.0796, 4.0806, and $4.0810 \AA$ for 250 , 500 and $1000 \mathrm{~nm}$ PLZT films, respectively. On the other hand, the (002) peak position is slightly shifted towards lower diffraction angles with increasing film thickness (see Figure S1a). Meanwhile, the in-plane $a$-lattice parameters, calculated from the position of the (200) peaks, are also slightly increased with increasing film thickness. The $a$-lattice parameters are approximately 4.0689, 4.0706, and $4.0716 \AA$ for 250, 500 and $1000 \mathrm{~nm}$ PLZT films, respectively. In this study, the films are fully relaxed from the stress of the substrate because they are much thicker than the critical thickness ( 80 nm) [35]. Figure S1c plots the $c / a$ ratio as a function of film thickness, in which it decreases slightly from 1.0026 to 1.0023 as the film thickness increases from 250 to $1000 \mathrm{~nm}$. The peak intensity of (002) and (200) $(\mathrm{I}(002) / \mathrm{I}(200))$ is also presented as a function of the film thickness in Figure S1c. The result shows that the greater the increase in the $(002) /(200)$ ratio, the greater the degree of $c$-axis domain switching in the films. The microstructure of PLZT films can be analyzed using cross-sectional SEM measurement, illustrated in Figure 1b, in which all PLZT films show dense structure. 
(a)

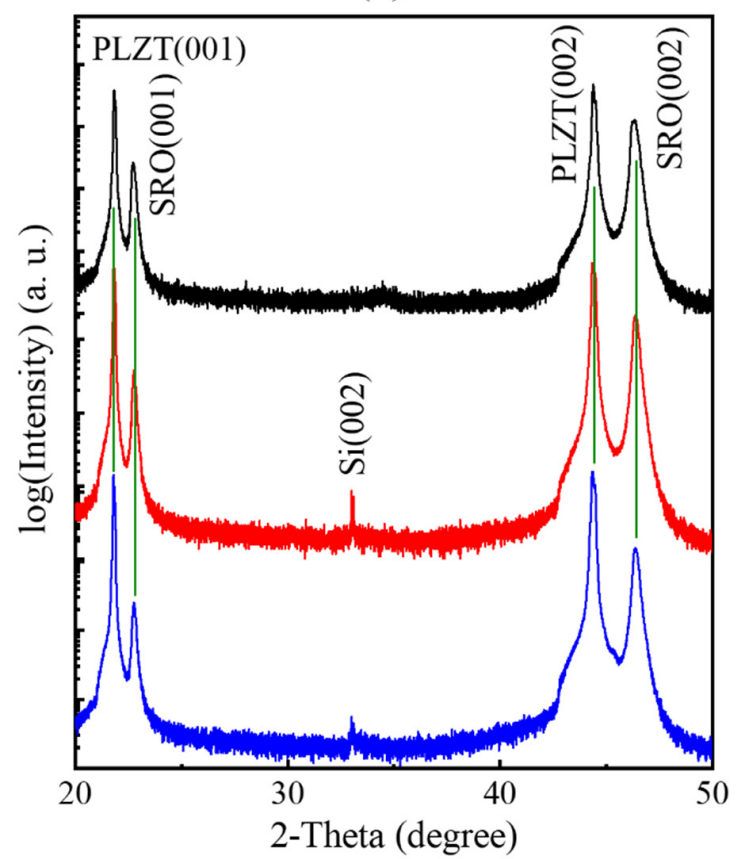

(b)
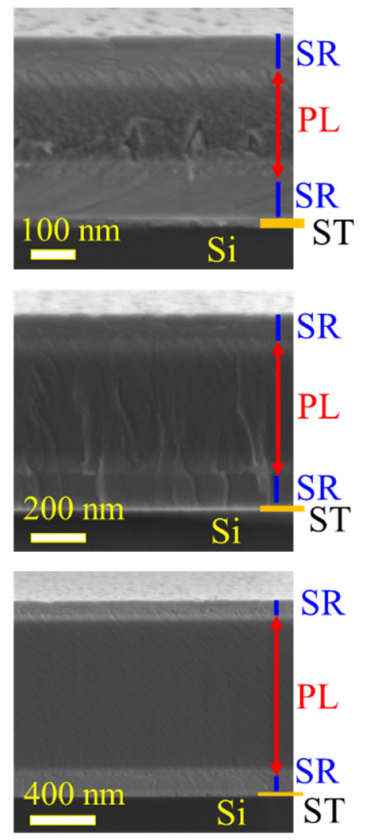

Figure 1. (a) XRD theta-2theta patterns and (b) corresponding cross-section SEM images of PLZT films.

The polarization hysteresis $(P-E)$ loops and corresponding switching current $\left(I_{S W^{-}} E\right)$ curves of the PLZT films with various film thicknesses, measured to a maximum electric field of $800 \mathrm{kV} / \mathrm{cm}$ and $1 \mathrm{kHz}$, are shown in Figure S2a,b. Figure S2a shows that all the films exhibit slim $P-E$ hysteresis loops with low remanent polarization $\left(P_{r} \approx 2-3 \mu \mathrm{C} / \mathrm{cm}^{2}\right)$ and small coercive field $\left(E_{c} \approx 20 \mathrm{kV} / \mathrm{cm}\right)$. A slim $P$-E loop is one of the typical features of relaxor ferroelectric behavior [36-38], which is mainly attributed to the presence of polar nano-regions [39-41]. The slim P-E loop of relaxor materials can be maintained under high electric fields, which results in large energy storage density and high energy efficiency [37,42-45]. As shown in Figure S3a, moreover, the broad dielectric constant peaks with the shift of dielectric maxima towards a higher temperature with increasing frequency are observed in the PLZT films in this study, which is also another behavior characteristic of relaxors [42,46-48]. A similar result has also been observed for the sol-gel $\mathrm{Pb}_{0.92} \mathrm{La}_{0.08} \mathrm{Zr}_{0.52} \mathrm{Ti}_{0.48} \mathrm{O}_{3}$ films [49].

In contrast to normal ferroelectrics in that the $I_{S W}-E$ curves exhibit two sharp peaks of polarization switching at a high $E_{c}$ value, relaxor ferroelectrics show the rounded $I_{S W}-E$ curves with the switching peaks at a low $E_{c}$ value (near the zero field), due to the phase transition from ferroelectric macrodomains in normal ferroelectrics to polar nanoregions in relaxors [50-52]. In this study, the four peaks present in the $I_{S W^{-}} E$ curves are observed in the relaxor PLZT films, in which the peak 'I' (Figure S2b) could be related to the electricfield-induced transition from a weak polar state (polar nanoregions) to a strong polar state, meanwhile the peak ' $\mathrm{II}^{\prime}$ (Figure S2b) illustrates that the strong polar state returns back to relaxor state [53,54]. Moreover, the same value of switching peaks during loading (peak ' $\mathrm{I}^{\prime}$ ) and unloading (peak ' $\mathrm{II}^{\prime}$ ) the electric field process are observed in the $I_{S W^{-}}-E$ curves, which indicates that there is no irreversible electric-field-induced transition [53], on the other hand, no evidence of domain switching is observed in the PLZT films.

The frequency dependent dielectric constant, dielectric loss, tunability and FOM of the relaxor-ferroelectric PLZT films have been investigated. Figure $2 \mathrm{a}-\mathrm{c}$ illustrates the variation of the dielectric constant with electric field ( $\varepsilon-E$ curves) for 250,500 and $1000 \mathrm{~nm}$ PLZT films, measured at a maximum applied electric field $\left(E_{a p, \max }\right)$ of $800 \mathrm{kV} / \mathrm{cm}$ and at various frequencies. At zero bias, the dielectric constant values decreases with 
the increase in frequency (more information can be seen in Figure 4a and Figure S3b). Whereas, as can be seen in Figure 2a-c and Figure S3c, the dielectric constant saturates to a constant value at high electric-field region, regardless of frequency. It is well-known that the dielectric constant of dielectric materials is due to the contribution of two effects: intrinsic and extrinsic effects. The effect of intrinsic contribution on the dielectric constant is usually caused by deformation of the crystalline elemental cell. Meanwhile, the extrinsic contribution to dielectric constant is mainly governed by domain wall mobility and the interfacial layer near the electrode and the dielectric material.

In general, the decrease in the dielectric constant with increase in frequency could be attributed to the contribution of various effects, such as electronic polarization (occurs at frequencies up to $10^{13} \mathrm{kHz}$ ), ionic polarization (up to $10^{10} \mathrm{kHz}$ ), dipolar polarization (up to $10^{7} \mathrm{kHz}$ ) and space-charge polarization (up to $10^{2} \mathrm{kHz}$ ) [55,56]. Higher values of dielectric constant at low frequency are due to the contribution of all the various types of polarizations in the capacitors. In the present case, therefore, it is clear that the decrease in the dielectric constant of PLZT films at higher frequencies is due to the reduction of space-charge polarization effect. At lower frequencies, higher values of dielectric constant are associated with the accumulation of space-charge polarization at the grain boundaries $[57,58]$, which can be explained using the Maxwell-Wagner polarization effect, under the assumption that the grains in the sample are separated by the insulating inter-grain barriers (leading to a formation of the 'boundary-layer capacitor' within the sample) [59-61]. The dielectric constant $\left(\varepsilon_{r}\right)$ of a ferroelectric material due to the motion of domain walls under various frequencies $(f)$ can be described in terms of the Rayleigh model [62-65]:

$$
\begin{gathered}
\varepsilon_{r}=\varepsilon_{r}(f)+\alpha_{e}(f) E_{a p, \max } \\
\varepsilon_{r}(f)=\varepsilon_{r, \text { initial }}-e \ln (f) \\
\alpha_{e}(f)=\alpha_{e, \text { initial }}-a \ln (f)
\end{gathered}
$$

where $\varepsilon_{r, \text { initial }}, \alpha_{e, \text { initial }}$ and $E_{a p, \text { max }}$ are the reversible dielectric constant at zero electric field, the irreversible Rayleigh parameter and the applied electric field, respectively. The magnitude of $\alpha_{e} E_{a p}$ represents the contribution of irreversible domain walls to dielectric properties. $e$ and $a$ are the frequency dependent dielectric constant and the Rayleigh parameters, respectively. Figure S4a shows the linear decrease of dielectric constant at zero field with the logarithm of the frequency. Therefore, it can be concluded that the extrinsic contribution to the dielectric constant of PLZT films is mainly attributed to domain wall motions, as similar to the case of ferroelectric films $[64,66]$.

In the high-field region, the dielectric constant decreases as the driving electric field increases beyond the $E_{c}$ value ( $E_{c}$ 一the field at the peaks of $\varepsilon$ - $E$ curve, where the $\varepsilon$ value is higher associated with high density of domain-wall motion and domain switching), as most switchable domains are aligned in the same direction of DC bias field, and also as the disappearance of the domain wall occurs. Therefore, the dielectric constant is small, as it is mainly associated with the variation of dipoles (hereafter known as the intrinsic contribution) [66,67]. Figure S3c indicates that the forward and backward curves of $\varepsilon-E$ for PLZT films, measured at $800 \mathrm{kV} / \mathrm{cm}$ and various frequencies, are nearly overlapping in the high-field regions $(-500 \mathrm{kV} / \mathrm{cm}$ to $-800 \mathrm{kV} / \mathrm{cm})$. In other words, the $\varepsilon-E$ curves of PLZT films are independent of measured frequency in the high-field regions.

To investigate the film thickness dependence of the dielectric constant, the $\varepsilon-E$ curves of PLZT films with film thickness from $250-1000 \mathrm{~nm}$, measured at $800 \mathrm{kV} / \mathrm{cm}$ and $100 \mathrm{kHz}$, are compared in Figure $2 \mathrm{~d}$. The results indicate that the dielectric constant at zero electric field $\left(\varepsilon_{r, 0 V}\right)$ increases with increasing film thickness (see also in Figure S4b), and moreover the dielectric constant is near-constant at higher electric fields (Figure S3c,d). Previous reports indicated that a reduction in dielectric constant in ferroelectric films can be explained by the formation of a thin layer with lower dielectric constant, due to the concentration of space charge carrier as oxygen vacancies and/or imperfection induced during film growth, near the film/electrode interfaces $[14,32,66,68]$. 
If $C_{P}$ is the capacitance due to the PLZT film and $C_{i}$ is the interfacial capacitance between film and electrode, the effective (measured) capacitance $\left(C_{e f f}\right)$ can be given as [69,70]:

$$
C_{e f f}=\frac{C_{P} C_{i}}{C_{P}+C_{i}}
$$

Equation (6) can be then expresses as follow:

$$
\frac{A}{C_{e f f}}=\frac{A}{C_{i}}+\frac{A}{C_{P}}=\frac{t_{i}}{\varepsilon_{i} \varepsilon_{0}}+\frac{t-t_{i}}{\varepsilon_{P} \varepsilon_{0}}
$$

where $A$ is the surface area of top-electrode, and $t$ and $t_{i}$ are the total film thickness and the interfacial layer thickness, respectively. $\varepsilon_{P}$ and $\varepsilon_{i}$ are the dielectric constant of PLZT and interfacial layers, respectively. $\varepsilon_{0}\left(=8.854 \times 10^{-12} \mathrm{~F} / \mathrm{m}\right)$ is the dielectric constant of free space.

If $C_{P}<<C_{i}$, or in other words, the thickness of the PLZT film is much greater than of the the interfacial layer $\left(t_{P}=t-t_{i}>t_{\mathrm{i}}\right), C_{\text {eff }}$ will be equal to $C_{P}$. Therefore, at higher film thicknesses, $C_{\text {eff }}$ will tend towards the actual dielectric constant of the PLZT film. Figure S4b shows the $A / C$ ratio as a function of film thickness, in which the experimental data can be fitted by a linear relationship between the $A / C_{e f f}$ and the film thickness. It can be found that $t_{i} / \varepsilon_{i} \approx 0.046 \mathrm{~nm}$, which indicates the presence of the interfacial layer at the PLZT/SRO interface $[66,71,72]$.

The tunability of PLZT films' dependence on electric bias field are calculated from Figure $2 \mathrm{~d}$ and displayed in Figure 3a. According to Equation (1), tunability is mainly dependent upon the dielectric constants at zero bias field $\left(\varepsilon_{r, 0 V}\right)$ and at maximum applied electric field $\left(\varepsilon_{E_{a p, \text { max }}}\right)$. Under $E_{a p, \max }$ of $800 \mathrm{kV} / \mathrm{cm}$ and $100 \mathrm{kHz}$, the tunability of 250,500 and $1000 \mathrm{~nm}$ PLZT films is about $82.5,83.4$ and $86.0 \%$, respectively. On the other hand, the increasing film thickness results in a significant enhancement in tunability, due to an increase in both $\varepsilon_{r, 0 V}$ and $\left(\varepsilon_{r, 0 V}-\varepsilon_{E_{a p, \max }}\right)$ values, as discussed above. From the combination of tunability (Figure $3 \mathrm{a}$ ) and dielectric loss ( $\tan \delta$, at zero bias field, Figure $3 \mathrm{~b}$ ), the values of the corresponding FOM values are calculated as 31.8, 35.0 and 37.2 , for $250 \mathrm{~nm}, 500 \mathrm{~nm}$ and $1000 \mathrm{~nm}$-thick PLZT films, respectively.

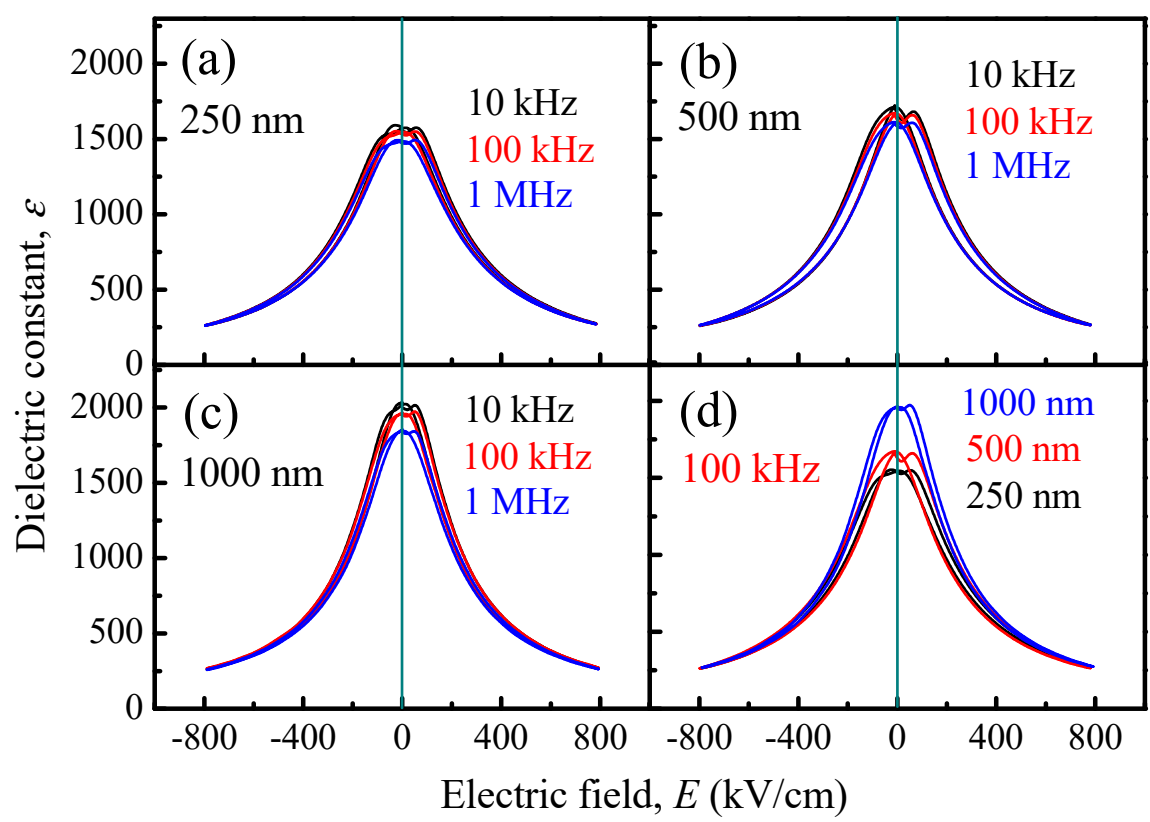

Figure 2. Dielectric constant-electric field ( $\varepsilon-E$ ) curves of (a) 250-nm, (b) 500-nm and (c) 1000-nm PLZT films, as a function of frequency. (d) Comparison of $\varepsilon-E$ curves of PLZT films measured at $100 \mathrm{kHz}$. The measurements were performed at $800 \mathrm{kV} / \mathrm{cm}$. 
(a)

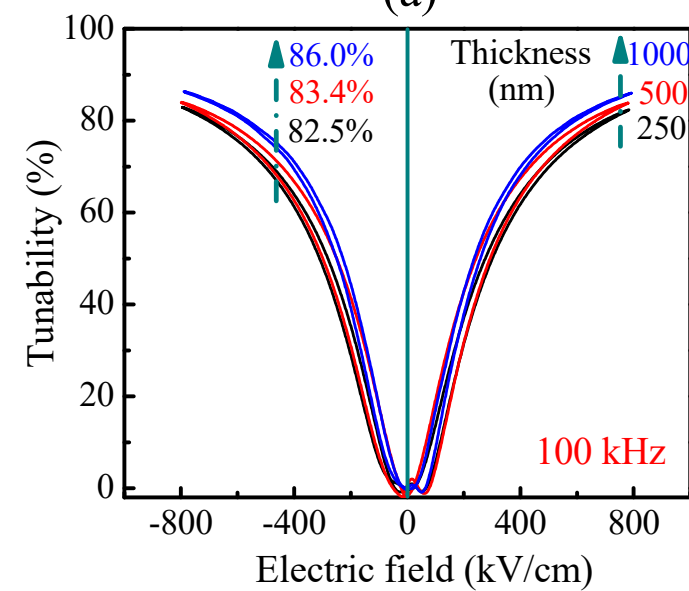

(b)

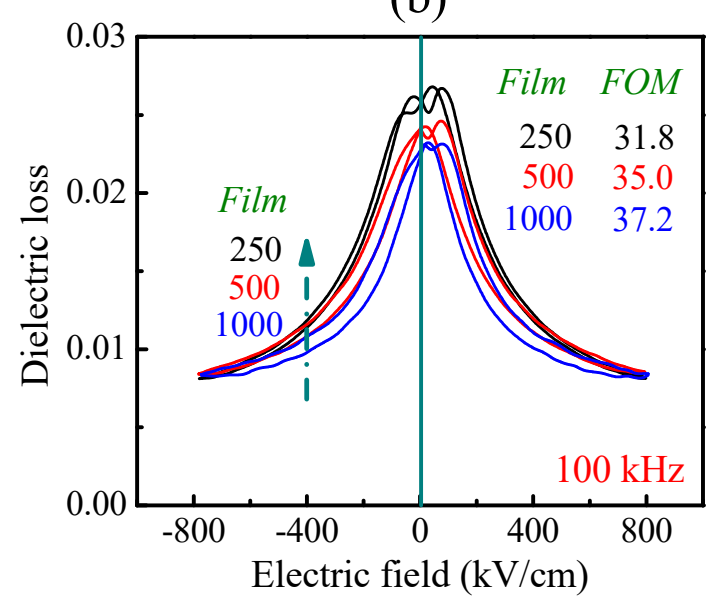

Figure 3. (a) Tunability curves which were calculated from the corresponding dielectric constant curves (Figure 2d), and (b) dielectric loss curves, of PLZT films as a function of film thickness measured at $800 \mathrm{kV} / \mathrm{cm}$ and $100 \mathrm{kHz}$.

Figure 4 shows the dielectric, tunability and FOM properties of the $1000 \mathrm{~nm}$ PLZT films, measured at $800 \mathrm{kV} / \mathrm{cm}$, as a function of operating frequency. The dielectric constant at a certain field $\left(\varepsilon_{E_{a p}}\right)$ is near-independent of frequency, and then $\varepsilon_{r, 0 V}$ and $\left(\varepsilon_{r, 0 V}-\varepsilon_{E_{a p, m a x}}\right)$ values show a similar trend, in which they decrease with increasing frequency (Figure $4 a$ ). Therefore, the tunability (as a ratio of $\left(\varepsilon_{r, 0 V}-\varepsilon_{E_{a p, \max }}\right)$ and $\varepsilon_{r, 0 V}$ values) is also slightly reduced. The decrease in $\varepsilon_{r, 0 V}$ value and tunability at high frequencies are related to free dipoles oscillating in an alternative applied electric field (such as the damped motions of dipole oscillators), due to the reduction in relaxation time ( $\tau=1$ /frequency) $[9,73,74]$. Moreover, due to the increase in dielectric loss with increasing frequency (Figure $4 \mathrm{~b}$ ), it is found that the reduction rate of the FOM is much higher than that of tunability (Figure S5b). The reduction of tunability and FOM is about $-2 \%$ and $-17 \%$, respectively, with the increase in frequency from $10 \mathrm{kHz}$ to $1 \mathrm{MHz}$ (Figure 4c,d).
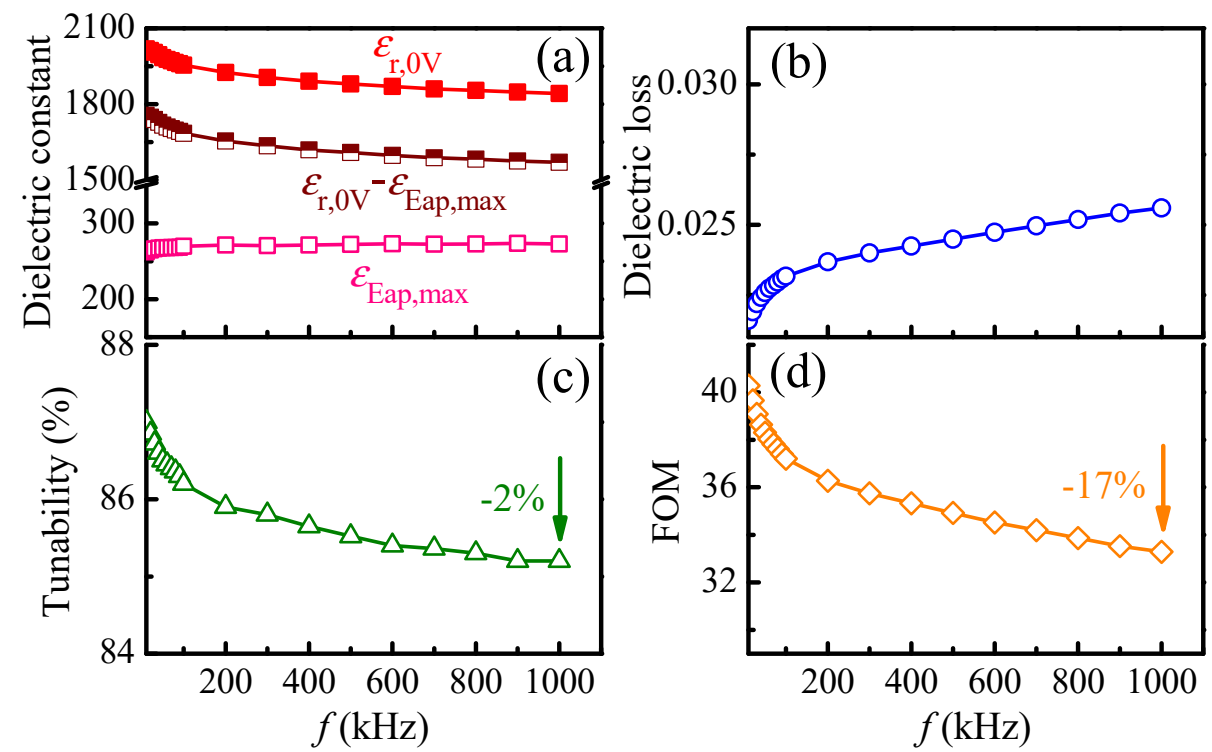

Figure 4. Operating frequency dependent (a) dielectric constant at zero field $\left(\varepsilon_{r, 0 V}\right)$ and at certain bias field $\left(\varepsilon_{E_{a p}}\right),(\mathbf{b})$ dielectric loss at zero field $(\tan \delta)$, (c) tunability $(T)$ and (d) figure-of-merit $(F O M)$, of 1000-nm PLZT films. The measurements were done at $800 \mathrm{kV} / \mathrm{cm}$. 
The maximum applied electric field $\left(E_{\text {ap, max }}\right)$ dependence of the $\varepsilon-E$ curves of $1000 \mathrm{~nm}$ PLZT films measured at $100 \mathrm{kHz}$ is shown in Figure 5a. In general, the relationship between dielectric constant and applied electric field can be described by Johnson's formula $[75,76]$ :

$$
\varepsilon_{E}=\frac{\varepsilon_{r, 0 V}}{\left(1+\alpha \varepsilon_{r, 0 V} E^{2}\right)^{1 / 3}}
$$

where $\alpha$ is a positive constant. This equation is valid in cases wherein the value of $E$ is larger than that of the $E_{c}$ value.
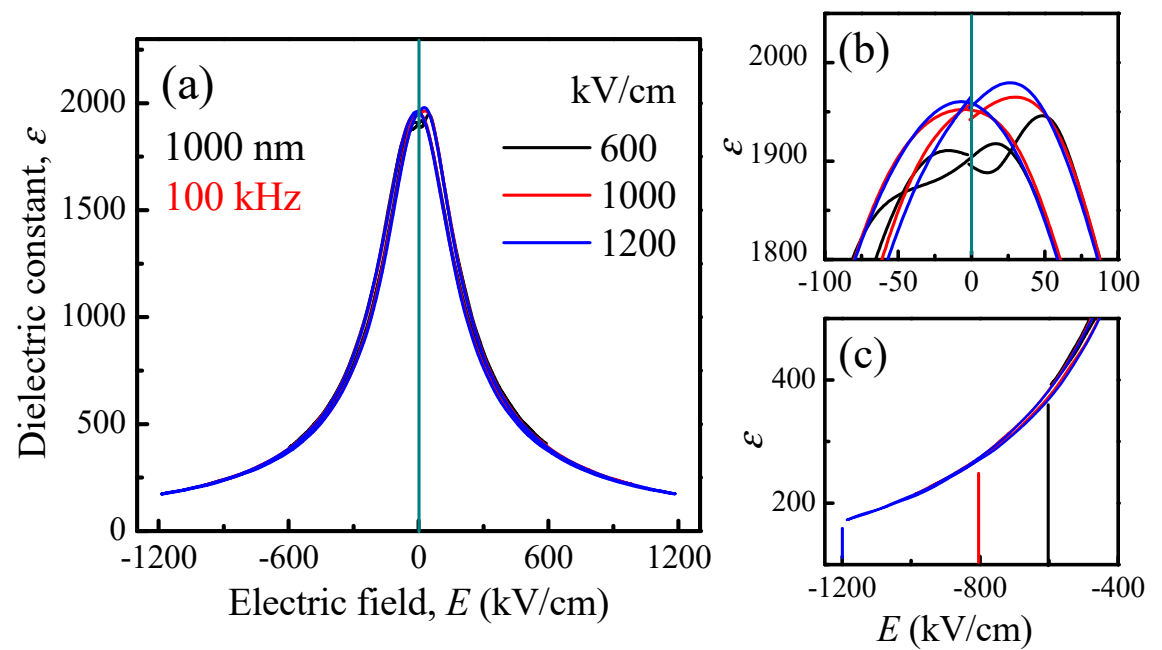

Figure 5. (a) Electric field dependent $\varepsilon$ - $E$ curves of $1000-\mathrm{nm}$ PLZT films measure at $100 \mathrm{kHz}$. Zoom-in (b) near the peaks and (c) in the high-field regions of $\varepsilon-E$ curves.

Equation (8) shows that the $\varepsilon_{r, 0 V}$ value of a dielectric material is independent of maximum applied electric field $\left(E_{a p, \max }\right)$, and that dielectric constant decreases with increasing electric field (in the large-field region, $E>E_{c}$ ). Figure $5 c$ illustrates that the $\varepsilon-E$ curves (both forward and backward) coincide with each other in the higher-field regions, following the relationship as indicated in Equation (8); this means that the dielectric constant value at $E_{a p, \max }$ decreases with increasing value of $E_{a p, \max }$ (Figure 6a). A magnification of the low-field region in Figure 5a, presented in Figure 5 b, shows that the $\varepsilon_{r, 0 V}$ value slightly increases with higher $E_{a p, \max }$ (see also in Figure 6a). The difference between calculated and experimental results for the $\varepsilon_{r, 0 V}$ value, in this case, can be explained by the existence of the polar nanoregions in the relaxor PLZT films. Cheng et al. indicated that there is a wide-range of the size distribution of the polar nanoregions, in which the polar nanoregions can change their size by applying electric field [77]. With the increase in applied electric field, the total dipolar moment per unit volume increases due to the increase in the dimension of polar nanoregions in some directions, but it decreases in other directions, thus resulting in an enhancement in $\varepsilon_{r, 0 V}$ value [77]. For comparison, the $\varepsilon-E$ curves of normal-ferroelectric $\mathrm{Pb}\left(\mathrm{Zr}_{0.52} \mathrm{Ti}_{0.48}\right) \mathrm{O}_{3}$ films have been measured and are shown in Figure S6. This result indicates that the dielectric constants of ferroelectric materials defined at zero-bias field and in the high-field region are independent of $E_{a p, \max }$. 

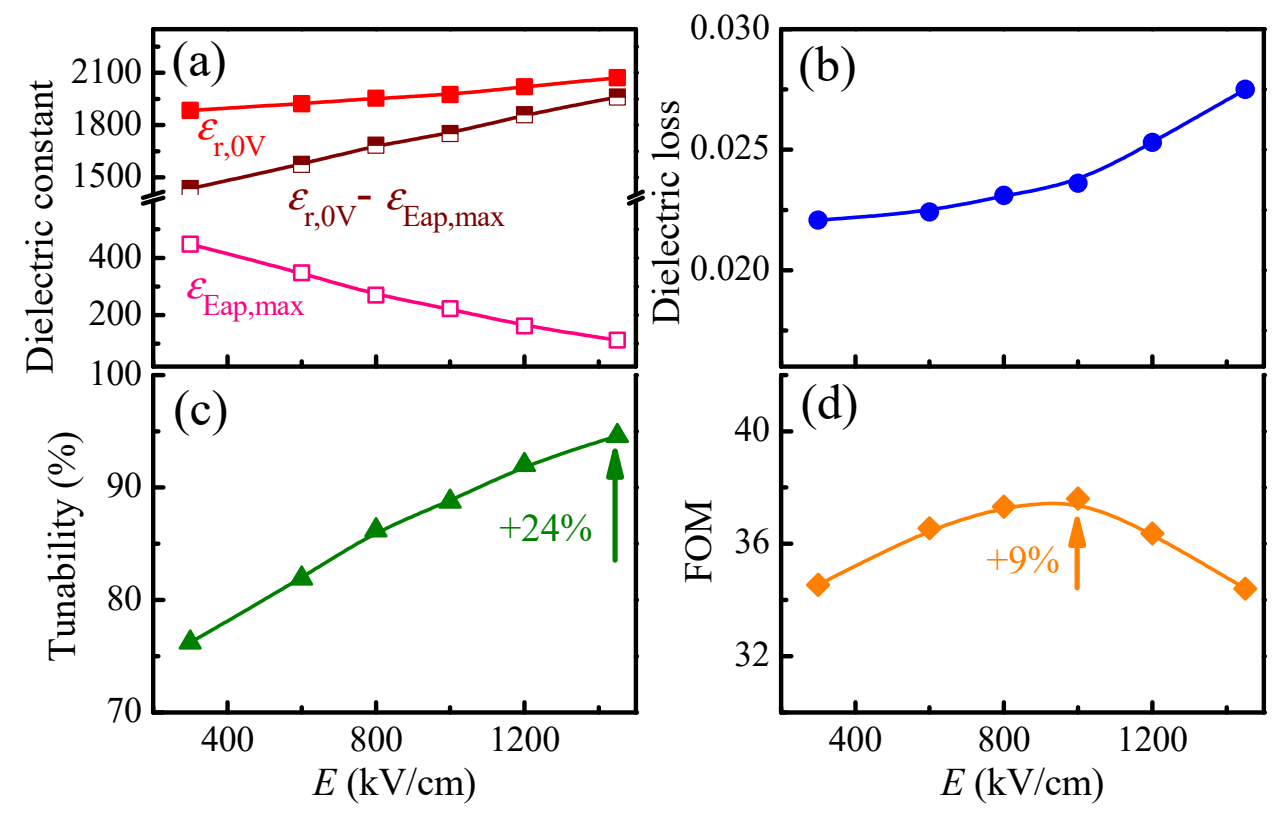

Figure 6. Applied electric-field dependent (a) dielectric constant at zero field $\left(\varepsilon_{r, 0 V}\right)$ and at certain bias field $\left(\varepsilon_{E_{a p, m a x}}\right),(\mathbf{b})$ dielectric loss at zero field $(\tan \delta),(\mathbf{c})$ tunability $(T)$ and (d) figure-of-merit (FOM), of 1000-nm PLZT films. The measurements were done at a frequency of $100 \mathrm{kHz}$.

The $E_{a p, \max }$-dependent dielectric constant and dielectric loss of $1000 \mathrm{~nm}$ PLZT films are presented in Figure 6a,b. Similar to that of electric field-dependent dielectric constant, the tunability increases with an increase in $E_{a p, \max }$, which can be explained by the faster enhancement rate of the difference between the $\varepsilon_{r, 0 V}$ and $\varepsilon_{E_{a p, \max }}$ values $\left(\varepsilon_{r, 0 V}-\varepsilon_{E_{a p, \max }}\right)$, as compared to the $\varepsilon_{r, 0 V}$ value. The highest tunability obtained at $1450 \mathrm{kV} / \mathrm{cm}$ is $94.6 \%$. Meanwhile, the $F O M$ reaches the maximum value ( 37.6) at $E_{a p, \max }$ of approximately $1000 \mathrm{kV} / \mathrm{cm}$ (Figure $6 \mathrm{~d}$ ). The reason for this behavior can be derived from the dielectric loss in Figure $6 \mathrm{~b}$ and from the tunability in Figure $6 \mathrm{c}$, in which the tunability increases gradually with $E_{a p, \max }$, but the dielectric loss increases slowly in the $E_{a p, \max }$-range of $300-1000 \mathrm{kV} / \mathrm{cm}$ and then rapidly with higher $E_{a p, \max }$ values. On the other hand, the largest FOM ( 37.6) is achieved at $E_{a p, \max }$ of $1000 \mathrm{kV} / \mathrm{cm}$, due to the optimum balance in tunability $(88.7 \%)$ and low dielectric loss (0.0236).

\section{Conclusions}

In conclusion, the dependence of dielectric and tunability properties and of the FOM of the relaxor-ferroelectric PLZT films on film thickness, frequency and applied electric field were investigated. Comparatively, thicker films have satisfactory dielectric constants, tunability and $F O M$ values, which can be attributed to the existence of a thin layer with lower dielectric constant near the interface between PLZT film and SRO electrode. A slight decrease in dielectric constant, tunability and FOM at high frequencies is caused by the oscillation of free dipoles in an alternating applied electric field. Moreover, the dielectric constant and tunability increase with increasing applied electric field. The $1000 \mathrm{~nm}$ PLZT film exhibits a high tunability of $94.6 \%$ at a maximum applied electric field of $1450 \mathrm{kV} / \mathrm{cm}$ at $100 \mathrm{kHz}$. Meanwhile, due to the combination of low dielectric loss (0.0236) and optimum tunability $(88.7 \%)$ at a maximum applied electric field of $1000 \mathrm{kV} / \mathrm{cm}$ and $100 \mathrm{kHz}$, the largest FOM (37.6) is achieved in the $1000 \mathrm{~nm}$ PLZT film, making it highly promising candidate for integration into dielectric microwave tunable devices.

Supplementary Materials: The following are available online at https://www.mdpi.com/article/10 .3390/ma14216448/s1, Figure S1: (a) XRD theta-2theta around the PLZT(002)/(200) peaks. (b) Variation in the unit-cell volume and (c) change in ratio between the intensity of (002) and (200) peaks and ratio between out-of-plane and in-plane $(c / a)$, of the PLZT films with changing film thickness; 
Figure S2: (a) Polarization hysteresis $(P-E)$ loops and (b) corresponding switching current $\left(I_{S W}-E\right)$ curves of PLZT films with various film thicknesses, measured at $800 \mathrm{kV} / \mathrm{cm}$ and $1 \mathrm{kHz}$. (c) $P$-E loops and (d) corresponding $I_{S W}-E$ curves of 1000-nm PLZT film, measured at $1 \mathrm{kHz}$ and under different applied electric fields (400, 800 and $1800 \mathrm{kV} / \mathrm{cm}$ ); Figure S3: (a) Dielectric constant versus temperature dependence at various frequencies. Zoom in (b) low-field region of Figure $2 c$, (c) high-field region of Figure 2c and (d) high-field region of Figure 2d; Figure S4: (a) Dependence of dielectric constant at zero-bias field $\left(\varepsilon_{r, 0 V}\right)$ of $1000-\mathrm{nm}$ film at $E_{a p, \max }$ of $800 \mathrm{kV} / \mathrm{cm}$ on frequency. (b) Inverse capacitance density $\left(A / C_{e f f}\right)$ and $\varepsilon_{r, 0 V}$ value as a function of PLZT film thickness; Figure S5: (a) Normalized dielectric constant at zero field $\left(\varepsilon_{r, 0 \mathrm{~V}}\right)$ and the difference between $\varepsilon_{r, 0 \mathrm{~V}}$ and $\varepsilon_{E_{a p, m a x}}$ (dielectric at certain bias field) as a function of frequency. (b) Normalized tunability $(T)$ and figure-of-merit $(F O M)$ as a function of frequency. The measurements were done at $800 \mathrm{kV} / \mathrm{cm}$ for 1000-nm PLZT films; Figure S6: (a) Polarization hysteresis ( $P-E$ ) loop and switching current curve, measured at $200 \mathrm{kV} / \mathrm{cm}$ and $1 \mathrm{kHz}$; (b) Dielectric constant curves measured at $1 \mathrm{kHz}$ and various maximum applied electric fields ( $E_{a p, \max }$ of 250 and $500 \mathrm{kV} / \mathrm{cm}$ ), of normal-ferroelectric $\mathrm{Pb}\left(\mathrm{Zr}_{0.52} \mathrm{Ti}_{0.48}\right) \mathrm{O}_{3}$ films.

Author Contributions: Conceptualization, M.D.N., G.R. and H.N.V.; validation, M.D.N., D.T.T., H.T.D., C.T.Q.N., G.R. and H.N.V.; formal analysis, M.D.N., D.T.T., H.T.D. and C.T.Q.N.; investigation, M.D.N., G.R. and H.N.V.; data curation, M.D.N., D.T.T., H.T.D. and C.T.Q.N.; writing, M.D.N. and H.N.V.; writing-review and editing, M.D.N., G.R. and H.N.V.; supervision, M.D.N., G.R. and H.N.V. All authors have read and agreed to the published version of the manuscript.

Funding: This research was funded by the National Foundation for Science and Technology Development (NAFOSTED) of Vietnam under Grant No. 103.99-2018.23.

Institutional Review Board Statement: Not applicable.

Informed Consent Statement: Not applicable.

Data Availability Statement: Not applicable.

Conflicts of Interest: The authors declare no conflict of interest.

\section{References}

1. Fetisov, Y.K.; Srinivasan, G. Electrically tunable ferrite-ferroelectric microwave delay lines. Appl. Phys. Lett. 2005, 87, 103502. [CrossRef]

2. Kuylenstierna, D.; Vorobiev, A.; Linner, P.; Gevorgian, S. Ultrawide-band tunable true-time delay lines using ferroelectric varactors. IEEE Trans. Microw. Theory Tech. 2005, 53, 2164-2170. [CrossRef]

3. Courreges, S.; Zhao, Z.; Choi, K.; Hunt, A.; Papapolymerou, J. Electronically tunable ferroelectric devices for microwave applications. In Microwave and Millimeter Wave Technologies from Photonic Bandgap Devices to Antenna and Applications; Minin, I., Ed.; IntechOpen: London, UK, 2010; pp. 185-204.

4. Kong, L.B.; Li, S.; Zhang, T.S.; Zhai, J.W.; Boey, F.Y.C.; Ma, J. Electrically tunable dielectric materials and strategies to improve their performances. Prog. Mater. Sci. 2010, 55, 840-893. [CrossRef]

5. Liu, C.; Liu, P.; Yao, G.G.; Bian, X.B.; Jing, H.X.; Lu, X.G.; Gao, C.J. Improvement of dielectric thermal stability of BST ferroelectric material for tunable applications. Mater. Res. Bull. 2011, 46, 1510-1514. [CrossRef]

6. Kuanr, B.K.; Veerakumar, V.; Marson, R.; Mishra, S.R.; Camley, R.E.; Celinski, Z. Nonreciprocal microwave devices based on magnetic nanowires. Appl. Phys. Lett. 2009, 94, 202505. [CrossRef]

7. Tagantsev, A.K.; Sherman, V.O.; Astafiev, K.F.; Venkatesh, J.; Setter, N. Ferroelectric materials for microwave tunable applications. J. Electroceram. 2003, 11, 5-66. [CrossRef]

8. He, Y.; Bahr, B.; Si, M.; Ye, P.; Weinstein, D. A tunable ferroelectric based unreleased RF resonator. Microsyst. Nanoeng. $2020,6,8$. [CrossRef] [PubMed]

9. Han, S.W.; Lee, C.H.; Shin, H.; Lee, J.H.; Cha, H.Y. Investigation of frequency-dependent permittivity tunability of P(VDF-TrFE) metal-ferroelectric-metal capacitor. Results Phys. 2019, 12, 469-470. [CrossRef]

10. Tatarenko, A.S.; Bichurin, M.I. Microwave magnetoelectric devices. Adv. Condens. Matter Phys. 2012, 2012, 286562. [CrossRef]

11. Yu, S.; Li, L.; Zhang, W.; Sun, Z.; Dong, H. Multilayer thin films with compositional $\mathrm{PbZr}_{0.52} \mathrm{Ti}_{0.48} \mathrm{O}_{3} / \mathrm{Bi}_{1.5} \mathrm{Zn}_{1.0} \mathrm{Nb}_{1.5} \mathrm{O}_{7}$ layers for tunable applications. Sci. Rep. 2015, 5, 10173. [CrossRef] [PubMed]

12. Ahmed, A.; Goldthorpe, I.A.; Khandani, A.K. Electrically tunable materials for microwave applications. Appl. Phys. Rev. 2015, 2 , 011302. [CrossRef]

13. Nayak, M.; Tseng, T.Y. Dielectric tunability of barium strontium titanate films prepared by a sol-gel method. Thin Solid Film. 2002, 408, 194-199. [CrossRef]

14. Doan, T.M.; Lu, L.; Lai, M.O. Thickness dependence of structure, tunable and pyroelectric properties of laser-ablated $\mathrm{Ba}\left(\mathrm{Zr}_{0.25} \mathrm{Ti}_{0.75}\right) \mathrm{O}_{3}$ thin films. J. Phys. D Appl. Phys. 2010, 43, 035402. [CrossRef] 
15. Zhong, S.; Alpay, S.P.; Mantese, J.V. High dielectric tunability in ferroelectric-paraelectric bilayers and multilayer superlattices. Appl. Phys. Lett. 2006, 88, 132904. [CrossRef]

16. Corredores, Y.; Le Febvrier, A.; Castel, X.; Sauleau, R.; Benzerga, R.; Députier, S.; Guilloux-Viry, M.; Mekadmini, A.; Martin, N.; Tanné, G. Study of ferroelectric/dielectric multilayers for tunable stub resonator applications at microwaves. Thin Solid Film. 2014, 553, 109-113. [CrossRef]

17. Liu, M.; Ma, C.; Collins, G.; Liu, J.; Chen, C.; Alemayehu, A.D.; Subramanyam, G.; Ding, Y.; Chen, J.; Dai, C.; et al. Ferroelectric $\mathrm{BaTiO}_{3} / \mathrm{SrTiO}_{3}$ multilayered thin films for room-temperature tunable microwave elements. Nanoscale Res. Lett. $2013,8,338$. [CrossRef] [PubMed]

18. Nguyen, M.D.; Nguyen, C.T.Q.; Vu, H.N.; Rijnders, G. Experimental evidence of breakdown strength and its effect on energystorage performance in normal and relaxor ferroelectric films. Curr. Appl. Phys. 2019, 19, 1040-1045. [CrossRef]

19. Nguyen, M.D.; Houwman, E.P.; Rijnders, G. Energy storage performance and electric breakdown field of thin relaxor ferroelectric PLZT films using microstructure and growth orientation control. J. Phys. Chem. C 2018, 122, 15171-15179. [CrossRef]

20. Schneider, G.A. A Griffith type energy release rate model for dielectric breakdown under space charge limited conductivity. J. Mech. Phys. Solids 2013, 61, 78-90. [CrossRef]

21. Helgee, B.; Bjellheim, P. Electric breakdown strength of aromatic polymers: Dependence on film thickness and chemical structure. IEEE Trans. Electr. Insul. 1991, 26, 1147-1152. [CrossRef]

22. Kim, H.K.; Shi, F.G. Thickness dependent dielectric strength of a low-permittivity dielectric film. IEEE Trans. Dielectr. Electr. Insul. 2001, 8, 248-252. [CrossRef]

23. Neusel, C.; Schneider, G.A. Size-dependence of the dielectric breakdown strength from nano- to millimeter scale. J. Mech. Phys. Solids 2014, 63, 201-213. [CrossRef]

24. Neusel, C.; Schneider, G.A. Dependence of the breakdown strength on thickness and permittivity. In Proceedings of the 2013 IEEE International Conference on Solid Dielectrics (ICSD), Bologna, Italy, 30 June-4 July 2013; pp. 31-35.

25. Schroeder, H.; Schmitz, S. Thickness dependence of leakage currents in high-permittivity thin films. Appl. Phys. Lett. 2003, 83, 4381-4383. [CrossRef]

26. Zhang, Z.; Yang, Q.; Wu, S. Effect of $\mathrm{SiO}_{2}$ films with different thickness deposited on copper electrode surface for insulation properties of propylene carbonate. IEEE Trans. Dielectr. Electr. Insul. 2021, 28, 600-607. [CrossRef]

27. Marincel, D.M.; Jesse, S.; Belianinov, A.; Okatan, M.B.; Kalinin, S.V.; Jackson, T.N.; Randall, C.A.; Trolier-McKinstry, S. A-site stoichiometry and piezoelectric response in thin film $\mathrm{PbZr}_{1-\mathrm{x}} \mathrm{Ti}_{\mathrm{x}} \mathrm{O}_{3}$. J. Appl. Phys. 2015, 117, 204104. [CrossRef]

28. Hu, Z.; Ma, B.; Liu, S.; Narayanan, M.; Balachandran, U. Relaxor behavior and energy storage performance of ferroelectric PLZT thin films with different $\mathrm{Zr} / \mathrm{Ti}$ ratios. Ceram. Inter. 2014, 40, 557-562. [CrossRef]

29. Narayanan, M.; Tong, S.; Liu, S.; Ma, B.; Balachandran, U. Estimation of intrinsic contribution to dielectric response of $\mathrm{Pb}_{0.92} \mathrm{La}_{0.08} \mathrm{Zr}_{0.52} \mathrm{Ti}_{0.48} \mathrm{O}_{3}$ thin films at low frequencies using high bias fields. Appl. Phys. Lett. 2013, 102, 062906. [CrossRef]

30. Tong, S.; Ma, B.; Narayanan, M.; Liu, S.; Koritala, R.; Balachandran, U.; Shi, D. Lead lanthanum zirconate titanate ceramic thin films for energy storage. ACS Appl. Mater. Interfaces 2013, 5, 1474-1480. [CrossRef]

31. Ni, B.; Peng, D.; Wu, W.; Meng, Z. Tunable properties of $\mathrm{Pb}_{\mathrm{x}} \mathrm{Sr}_{1-\mathrm{x}} \mathrm{TiO}_{3}$ thin films. In Proceedings of the Fifth International Conference on Thin Film Physics and Applications (Proc. SPIE 5774), Shanghai, China, 31 May—2 June 2004; SPIE: Shanghai, China, 2004; Volume 5774, pp. 250-253.

32. Song, S.; Zhai, J.; Gao, L.; Yao, X.; Lu, S.; Xu, Z. Thickness-dependent dielectric and tunable properties of barium stannate titanate thin films. J. Appl. Phys. 2009, 106, 024104. [CrossRef]

33. Sun, X.; Yang, Y.; Zhang, Q.; Zhou, X.; Hu, Z.; Huang, C. Enhanced dielectric and tunable properties of barium strontium titanate thin films through introducing $\mathrm{Nd}\left(\mathrm{Zn}_{1 / 2} \mathrm{Ti}_{1 / 2}\right) \mathrm{O}_{3}$ and adjusting Ba/Sr. J. Mater. Sci. 2014, 49, 1058-1065. [CrossRef]

34. Alema, F.; Pokhodnya, K. Dielectric properties of $\mathrm{BaMg}_{1 / 3} \mathrm{Nb}_{2 / 3} \mathrm{O}_{3}$ doped $\mathrm{Ba}_{0.45} \mathrm{Sr}_{0.55} \mathrm{TiO}_{3}$ thin films for tunable microwave applications. J. Adv. Dielectr. 2015, 5, 1550030. [CrossRef]

35. Gariglio, S.; Stucki, N.; Triscone, J.M.; Triscone, G. Strain relaxation and critical temperature in epitaxial ferroelectric $\mathrm{Pb}\left(\mathrm{Zr}_{0.20} \mathrm{Ti}_{0.80}\right) \mathrm{O}_{3}$ thin films. Appl. Phys. Lett. 2007, 90, 202905. [CrossRef]

36. $\mathrm{Hu}, \mathrm{Q}$.; Wei, X. Abnormal phase transition and polarization mismatch phenomena in $\mathrm{BaTiO}_{3}$-based relaxor ferroelectrics. J. Adv. Dielectr. 2019, 09, 1930002. [CrossRef]

37. Bhattarai, M.K.; Mishra, K.K.; Dugu, S.; Instan, A.A.; Katiyar, R.S. Ferroelectric ordering and energy storage density of thin films capacitor by doping $\mathrm{La}^{3+}$ and $\mathrm{Sc}^{3+}$ on $\mathrm{Pb}\left(\mathrm{Zr}_{0.53} \mathrm{Ti}_{0.47}\right) \mathrm{O}_{3}$ using pulse laser deposition technique. Appl. Phys. Lett. 2019, 114, 223902. [CrossRef]

38. Nguyen, M.D.; Houwman, E.P.; Do, M.T.; Rijnders, G. Relaxor-ferroelectric thin film heterostructure with large imprint for high energy-storage performance at low operating voltage. Energy Storage Mater. 2020, 25, 193-201. [CrossRef]

39. Polinger, V.; Bersuker, I.B. Origin of polar nanoregions and relaxor properties of ferroelectrics. Phys. Rev. B 2018, $98,214102$. [CrossRef]

40. Xu, G.; Zhong, Z.; Bing, Y.; Ye, Z.G.; Shirane, G. Electric-field-induced redistribution of polar nano-regions in a relaxor ferroelectric. Nat. Mater. 2006, 5, 134-140. [CrossRef] [PubMed]

41. Liu, N.; Dittmer, R.; Stark, R.W.; Dietz, C. Visualization of polar nanoregions in lead-free relaxors via piezoresponse force microscopy in torsional dual AC resonance tracking mode. Nanoscale 2015, 7, 11787-11796. [CrossRef] 
42. Zhou, M.; Liang, R.; Zhou, Z.; Dong, X. Combining high energy efficiency and fast charge-discharge capability in novel $\mathrm{BaTiO}_{3}$-based relaxor ferroelectric ceramic for energy-storage. Ceram. Inter. 2019, 45, 3582-3590. [CrossRef]

43. Pan, H.; Ma, J.; Ma, J.; Zhang, Q.; Liu, X.; Guan, B.; Gu, L.; Zhang, X.; Zhang, Y.J.; Li, L.; et al. Giant energy density and high efficiency achieved in bismuth ferrite-based film capacitors via domain engineering. Nat. Commun. 2018, 9, 1813. [CrossRef] [PubMed]

44. Kim, J.; Saremi, S.; Acharya, M.; Velarde, G.; Parsonnet, E.; Donahue, P.; Qualls, A.; Garcia, D.; Martin, L.W. Ultrahigh capacitive energy density in ion-bombarded relaxor ferroelectric films. Science 2020, 369, 81-84. [CrossRef]

45. Nguyen, M.D.; Houwman, E.P.; Dekkers, M.; Nguyen, C.T.Q.; Vu, H.N.; Rijnders, G. Enhanced energy storage density and energy efficiency of epitaxial $\mathrm{Pb}_{0.9} \mathrm{La}_{0.1}\left(\mathrm{Zr}_{0.52} \mathrm{Ti}_{0.48}\right) \mathrm{O}_{3}$ relaxor-ferroelectric thin-films deposited on silicon by pulsed laser deposition. APL Mater. 2016, 4, 080701. [CrossRef]

46. Gong, G.; Zerihun, G.; Fang, Y.; Huang, S.; Yin, C.; Yuan, S. Relaxor behavior and large room-temperature polarization of ferroelectric $\mathrm{Sr}_{4} \mathrm{CaBiTi}_{3} \mathrm{Nb}_{7} \mathrm{O}_{30}$ ceramics. J. Am. Ceram. Soc. 2015, 98, 109-113. [CrossRef]

47. Liu, X.; Fan, H.; Shi, J.; Li, Q. Origin of anomalous giant dielectric performance in novel perovskite: $\mathrm{Bi}_{0.5-\mathrm{x}} \mathrm{La}_{\mathrm{x}} \mathrm{Na}_{0.5-\mathrm{x}} \mathrm{Li}_{\mathrm{x}} \mathrm{Ti}_{1-\mathrm{y}} \mathrm{M}_{\mathrm{y}} \mathrm{O}_{3}$ $\left(\mathrm{M}=\mathrm{Mg}^{2+}, \mathrm{Ga}^{3+}\right)$. Sci. Rep. 2015, 5, 12699. [CrossRef]

48. Liu, Y.; Lin, Y.T.; Haibibu, A.; Xu, W.; Zhou, Y.; Li, L.; Kim, S.H.; Wang, Q. Relaxor ferroelectric polymers: Insight into high electrical energy storage properties from a molecular perspective. Small Sci. 2021, 1, 2000061. [CrossRef]

49. Ma, B.; Hu, Z.; Liu, S.; Tong, S.; Narayanan, M.; Koritala, R.E.; Balachandran, U. Temperature-dependent dielectric nonlinearity of relaxor ferroelectric $\mathrm{Pb}_{0.92} \mathrm{La}_{0.08} \mathrm{Zr}_{0.52} \mathrm{Ti}_{0.48} \mathrm{O}_{3}$ thin films. Appl. Phys. Lett. 2013, 102, 202901. [CrossRef]

50. Zhang, L.; Zhao, C.; Zheng, T.; Wu, J. Large electrocaloric response with superior temperature stability in $\mathrm{NaNbO}_{3}$-based relaxor ferroelectrics benefiting from the crossover region. J. Mater. Chem. A 2021, 9, 2806-2814. [CrossRef]

51. Dang, H.T.; Trinh, T.T.; Nguyen, C.T.Q.; Do, T.V.; Nguyen, M.D.; Vu, H.N. Enhancement of relaxor behavior by La doping and its influence on the energy storage performance and electric breakdown strength of ferroelectric $\mathrm{Pb}\left(\mathrm{Zr}_{0.52} \mathrm{Ti}_{0.48}\right) \mathrm{O}_{3}$ thin films. Mater. Chem. Phys. 2019, 234, 210-216. [CrossRef]

52. Li, J.; Li, J.; Qin, S.; Su, X.; Qiao, L.; Wang, Y.; Lookman, T.; Bai, Y. Effects of long- and short-range ferroelectric order on the electrocaloric effect in relaxor ferroelectric ceramics. Phys. Rev. Appl. 2019, 11, 044032. [CrossRef]

53. Wu, J.; Zhang, H.; Huang, C.H.; Tseng, C.W.; Meng, N.; Koval, V.; Chou, Y.C.; Zhang, Z.; Yan, H. Ultrahigh field-induced strain in lead-free ceramics. Nano Energy 2020, 76, 105037. [CrossRef]

54. Sun, R.; Wang, X.; Shi, J.; Wang, L. Dielectric and polar order behaviors of $\mathrm{BaTiO}_{3}-\mathrm{Bi}\left(\mathrm{Mg}_{1 / 2} \mathrm{Ti}_{1 / 2}\right) \mathrm{O}_{3}$ ceramics. Appl. Phys. A 2011, 104, 129-133. [CrossRef]

55. Beloborodov, R.; Pervukhina, M.; Han, T.; Josh, M. Experimental characterization of dielectric properties in fluid saturated artificial shales. Geofluids 2017, 2017, 1019461. [CrossRef]

56. Wilson, J.N.; Frost, J.M.; Wallace, S.K.; Walsh, A. Dielectric and ferroic properties of metal halide perovskites. APL Mater. 2019, 7, 010901. [CrossRef]

57. Rayssi, C.; El Kossi, S.; Dhahri, J.; Khirouni, K. Frequency and temperature-dependence of dielectric permittivity and electric modulus studies of the solid solution $\mathrm{Ca}_{0.85} \mathrm{Er}_{0.1} \mathrm{Ti}_{1-\mathrm{x}} \mathrm{Co}_{4 \mathrm{x} / 3} \mathrm{O}_{3}(0 \leq \mathrm{x} \leq 0.1)$. RSC Adv. 2018, 8, 17139-17150. [CrossRef]

58. Waser, R.; Hagenbeck, R. Grain boundaries in dielectric and mixed-conducting ceramics. Acta Mater. 2000, 48, 797-825. [CrossRef]

59. Iwamoto, M. Maxwell-Wagner effect. In Encyclopedia of Nanotechnology; Bhushan, B., Ed.; Springer: Dordrecht, The Netherlands, 2012; pp. 1276-1285.

60. Li, Y.J.; Chen, X.M.; Hou, R.Z.; Tang, T.H. Maxwell-Wagner characterization of dielectric relaxation in $\mathrm{Ni}_{0.8} \mathrm{Zn}_{0.2} \mathrm{Fe}_{2} \mathrm{O}_{4} / \mathrm{Sr}_{0.5} \mathrm{Ba}_{0.5}$ $\mathrm{Nb}_{2} \mathrm{O}_{6}$ composite. Solid State Commun. 2006, 137, 120-125. [CrossRef]

61. Mohapatra, A.; Das, P.R.; Choudhary, R.N.P. Structural and electrical properties of La modified $\mathrm{Bi}_{5} \mathrm{Ti}_{3} \mathrm{FeO}_{15} \mathrm{Ceramics}$ J. Mater Sci. Mater. Electron. 2015, 26, 3035-3043. [CrossRef]

62. García, J.E.; Pérez, R.; Ochoa, D.A.; Albareda, A.; Lente, M.H.; Eiras, J.A. Evaluation of domain wall motion in lead zirconate titanate ceramics by nonlinear response measurements. J. Appl. Phys. 2008, 103, 054108. [CrossRef]

63. Denis, L.M.; Esteves, G.; Walker, J.; Jones, J.L.; Trolier-McKinstry, S. Thickness dependent response of domain wall motion in declamped $\{001\} \mathrm{Pb}\left(\mathrm{Zr}_{0.3} \mathrm{Ti}_{0.7}\right) \mathrm{O}_{3}$ thin films. Acta Mater. 2018, 151, 243-252. [CrossRef]

64. Taylor, D.V.; Damjanovic, D. Evidence of domain wall contribution to the dielectric permittivity in PZT thin films at sub-switching fields. J. Appl. Phys. 1997, 82, 1973-1975. [CrossRef]

65. Damjanovic, D. Logarithmic frequency dependence of the piezoelectric effect due to pinning of ferroelectric-ferroelastic domain walls. Phys. Rev. B 1997, 55, R649-R652. [CrossRef]

66. Pérez de la Cruz, J.; Joanni, E.; Vilarinho, P.M.; Kholkin, A.L. Thickness effect on the dielectric, ferroelectric, and piezoelectric properties of ferroelectric lead zirconate titanate thin films. J. Appl. Phys. 2010, 108, 114106. [CrossRef]

67. Gong, W.; Li, J.F.; Chu, X.; Gui, Z.; Li, L. Combined effect of preferential orientation and Zr/Ti atomic ratio on electrical properties of $\mathrm{Pb}\left(\mathrm{Zr}_{\mathrm{x}} \mathrm{Ti}_{1-\mathrm{x}}\right) \mathrm{O}_{3}$ thin films. J. Appl. Phys. 2004, 96, 590-595. [CrossRef]

68. Oh, J.; Moon, T.; Kim, T.G.; Kim, C.; Lee, J.H.; Lee, S.Y.; Park, B. The dependence of dielectric properties on the thickness of (Ba,Sr) $\mathrm{TiO}_{3}$ thin films. Curr. Appl. Phys. 2007, 7, 168-171. [CrossRef]

69. Do, M.T.; Gauquelin, N.; Nguyen, M.D.; Wang, J.; Verbeeck, J.; Blom, F.; Koster, G.; Houwman, E.P.; Rijnders, G. Interfacial dielectric layer as an origin of polarization fatigue in ferroelectric capacitors. Sci. Rep. 2020, 10, 7310. [CrossRef] [PubMed] 
70. Yang, H.; Suvorova, N.A.; Jain, M.; Kang, B.S.; Li, Y.; Hawley, M.E.; Dowden, P.C.; DePaula, R.F.; Jia, Q.X.; Lu, C.J. Effective thickness and dielectric constant of interfacial layers of $\mathrm{Pt} / \mathrm{Bi}_{3.15} \mathrm{Nd}_{0.85} \mathrm{Ti}_{3} \mathrm{O}_{12} / \mathrm{SrRuO}_{3}$ capacitors. Appl. Phys. Lett. 2007, 90, 232909. [CrossRef]

71. Basceri, C.; Streiffer, S.K.; Kingon, A.I.; Waser, R. The dielectric response as a function of temperature and film thickness of fiber-textured (Ba,Sr) $\mathrm{TiO}_{3}$ thin films grown by chemical vapor deposition. J. Appl. Phys. 1997, 82, 2497-2504. [CrossRef]

72. Thiruramanathan, P.; Sankar, S.; Marikani, A.; Madhavan, D.; Sharma, S.K. Thickness dependent structural and dielectric properties of calcium copper titanate thin films produced by spin-coating method for microelectronic devices. J. Electron. Mater. 2017, 46, 4468-4477. [CrossRef]

73. Jaiswal, A.; Das, R.; Maity, T.; Poddar, P. Dielectric and spin relaxation behaviour in $\mathrm{DyFeO}_{3}$ nanocrystals. J. Appl. Phys. 2011, 110, 124301. [CrossRef]

74. Tang, R.; Jiang, C.; Qian, W.; Jian, J.; Zhang, X.; Wang, H.; Yang, H. Dielectric relaxation, resonance and scaling behaviors in $\mathrm{Sr}_{3} \mathrm{Co}_{2} \mathrm{Fe}_{24} \mathrm{O}_{41}$ hexaferrite. Sci. Rep. 2015, 5, 13645. [CrossRef]

75. Placeres-Jiménez, R.; Rino, J.P.; Eiras, J.A. Modeling ferroelectric permittivity dependence on electric field and estimation of the intrinsic and extrinsic contributions. J. Phys. D Appl. Phys. 2015, 48, 035304. [CrossRef]

76. Placeres-Jiménez, R.; Rino, J.P.; Gonçalves, A.M.; Eiras, J.A. Nonlinear dielectric response and transient current: An effective potential for ferroelectric domain wall displacement. Appl. Phys. Lett. 2013, 103, 112901. [CrossRef]

77. Cheng, Z.Y.; Katiyar, R.S.; Yao, X.; Bhalla, A.S. Temperature dependence of the dielectric constant of relaxor ferroelectrics. Phys. Rev. B 1998, 57, 8166-8177. [CrossRef] 